\title{
Performance of tamboril Seedlings Produced in Three Different Tube Volumes
}

\author{
Teresa Aparecida Soares Freitas ${ }^{1}$, Poliana dos Santos Pereira da Silva ${ }^{1}$, \\ Júlia Borges Peixinho ${ }^{1}$, Andrea Vita Reis Mendonça ${ }^{1}$, Lucas Barbosa dos Santos ${ }^{1}$ \\ ${ }^{1}$ Centro de Ciências Agrárias, Ambientais e Biológicas - CCAAB, Universidade Federal do Recôncavo da Bahia - UFRB, \\ Cruz das Almas/BA, Brasil
}

\begin{abstract}
The objective of this study was to evaluate the performance of tamboril (Enterolobium contortisiliquum (Vell.) Morong) seedlings and define their time in the nursery. Two experiments were carried out; in the first, the seedlings remained in the nursery for 120 days, and height, diameter, root deformation \%, shoot dry mass, root system and leaf number were evaluated. In the second experiment, four seedlings of each repetition were transplanted into $35 \mathrm{x} 40 \mathrm{~cm}$ bags and then assessed for height, diameter and dry weight of the shoot and root system. Data were submitted to analysis of variance $(\alpha=0.05$ ), Tukey test at $5 \%$ (qualitative factor) and sequential regression (quantitative factors). The seedlings produced in higher-tube volumes achieved conditions for planting at 90 days, while those produced in the lowest volume achieved the same conditions only after 120 days. Therefore, $180 \mathrm{~cm}^{3}$ tubes and a 90 -day stay in the nursery are recommended.
\end{abstract}

Keywords: containers, growth, Enterolobium contortisiliquum (Vell.) Morong. 


\section{INTRODUCTION}

One of the major problems encountered in producing forest seedlings is the length of time they must remain in the nursery, so as not to affect survival or growth post-planting. According to Freitas et al. (2013), the tube volume used is an extremely important factor, since it directly interferes in the quality of the seedlings, in addition to influencing their length of stay in the nursery. Correia et al. (2013) points out that the tube volume also influences the space occupied by the seedlings in the nursery, the labor force used, the expenses for inputs and the transportation of these seedlings.

Oliveira et al. (2011) emphasize that techniques to evaluate seedling quality should be developed according to the size of the containers, as well as the ideal time for growing the seedlings in the nursery in order to provide the best growth.

Correia et al. (2013) and Gasparin et al. (2014) report the need for studies on seedling production beyond the nursery stage in order to confirm the differences between the methods applied for seedling production, thus allowing us to relate the variables that represent the quality of seedlings in both situations.

Knowledge about production techniques is not only important for commercial scale operations, but as reported by Barbosa et al. (2013), greater success in the ecological restoration process also stems from knowledge about the container in which the seedling is produced, thus highlighting the need for studies about the establishment of tree seedlings in the field.

Enterolobium contortisiliquum (Vell.) Morong is popularly known in Brazil as orelha-de-macaco or tamboril, and is found in pluvial and semi-deciduous forests, dispersed in several forest formations (Lorenzi, 2008). According to the same author, its wood is appropriate for manufacturing whole-trunk boats and canoes, toys, plywood and furniture frames. Additionally, it presents some tolerance to heavy metals, showing promise for research aimed at the revegetation of soils that contain excessive levels of these elements (Andrade, 2005; Trannin et al., 2001). Further, it also presents rapid initial growth (Araújo \& Sobrinho, 2011).

However, little is known about the length of the nursery stay of Enterolobium contortisiliquum seedlings as a function of the volume of the tube in which they are produced.

Therefore, the objective of this study is to evaluate the quality of Enterolobium contortisiliquum seedlings produced using different tube volumes in the nursery phase and their initial growth in the field, in addition to determining the stay of seedlings in the nursery.

\section{MATERIAL AND METHODS}

The experiment was carried out at the forest seedling nursery under $50 \%$ shading, located in the experimental field of the Federal University of Recôncavo da Bahia, in the municipality of Cruz das Almas, Bahia, Brazil.

Tamboril fruit was collected from matrix trees distributed across the Cruz das Almas campus. After collection, the fruit was benefited and the seeds were stored in a plastic container for 30 days. Prior to sowing, the seeds underwent mechanical scarification on the opposite side of the hilum using $n^{\circ} .80$ sand paper.

The experimental design of both phases of the experiment followed a completely randomized design of three treatments $\left(50,180\right.$ and $280 \mathrm{~cm}^{3}$ tubes) with four replications and 38 seedlings per replicate in the nursery stage, and four seedlings in the field phase.

Vivatto Plus substrate was used for seedling production, and the fertilizer was Osmocote (NPK 14-14-14) at a dose of $8 \mathrm{~g}$ per kilogram of substrate.

After the seedling production phase, four seedlings per replicate of each treatment were transplanted into $35 \times 40 \mathrm{~cm}$ bags (approximately $15.597 \mathrm{~cm}^{3}$ ) filled with soil from the planting area, and then fertilized with NPK 04-14-08 at the proportion of $100 \mathrm{~g}$ per bag in order to simulate an initial growth situation in the field.

Irrigation was performed twice a day using watering cans, taking into account climatic conditions.

Height and diameter evaluations started 30 days after sowing with the aid of a millimeter ruler and a pachymeter, respectively, at 15-day intervals, up to 120 days, with all seedlings being evaluated. The number of leaves of these seedlings was evaluated at 120 days.

The root system deformation percentage and root and shoot dry mass were evaluated at 90 and 120 days, using two seedlings per repetition of each treatment. In order to obtain the root deformation percentage, the roots were washed and evaluated for the number of 
roots emitted and the number of observed deformations, and the root system deformation percentages were then determined from these values. In order to obtain the shoot and root system dry masses, both systems were separated and placed in paper bags and taken to be dried in a forced circulation air oven at $70^{\circ} \mathrm{C}$ for 48 hours. The roots were washed in running water before being taken to the oven.

In the second phase, the seedlings were evaluated every 30 days for height and diameter, with the first evaluation being carried out at the time of transplantation into the bag, using a millimeter ruler and a manual pachymeter, respectively, until 120 days. At the end of 120 days, shoot dry mass, the root system dry mass and dry matter ratio between the root system and the shoot dry mass were obtained.

In order to obtain the shoot and root system dry mass, the shoots were separated from the root, placed into paper bags, and then placed in a forced circulation oven at a temperature of $65^{\circ} \mathrm{C}$ for 72 hours; the roots were manually separated from the soil before being taken to the oven.

The data were submitted to analysis of variance ( $\alpha=0.05$ ), with qualitative factors compared by the Tukey test at $5 \%$ probability, and sequential regression analysis for the quantitative variables.

\section{RESULTS AND DISCUSSION}

Figure 1 shows the performance of the Enterolobium contortisiliquum seedlings produced in tubes of 55,180 and $280 \mathrm{~cm}^{3}$ over 120 days, in which it could be observed that both seedling height and diameter were affected by the container in which the seedlings were produced throughout the whole production cycle.

Over the 120 days, the seedlings produced in the tube with the smallest volume $\left(55 \mathrm{~cm}^{3}\right)$ had lower performance for height and diameter compared to the other seedlings in larger tubes. After 120 days in the nursery, the seedlings produced in the smaller volume tube showed an average height and diameter of $10 \mathrm{~cm}$ and $3 \mathrm{~mm}$, respectively. By contrast, the seedlings produced in 180 and $280 \mathrm{~cm}^{3}$ containers were already $15 \mathrm{~cm}$ high and $3 \mathrm{~mm}$ in diameter after just 45 days post-planting; and this difference remained throughout the cycle.

Regardless of the species, the effect of the container volume used is observed from a certain period of the seedlings' permanence in the nursery. These differences in growth were observed for several forest species. Examples include the studies by José et al. (2005) for Schinus terebinthifolius, Freitas et al. (2013) and Eloy et al. (2014) for different species of Eucalyptus spp, and Alves et al. (2012) for Anadenanthera macrocarpa,
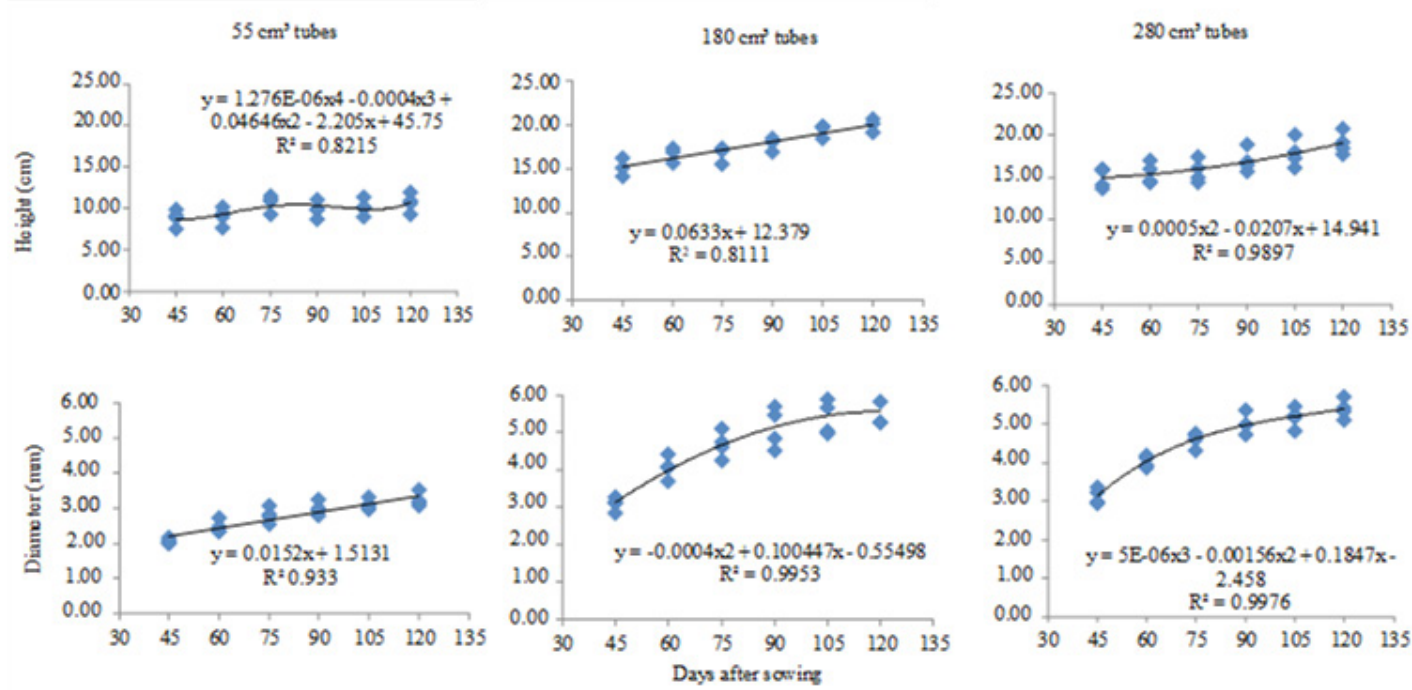

Figure 1. Growth in height $(\mathrm{cm})$ and diameter $(\mathrm{mm})$ of Enterolobium contortisiliquum seedlings produced in three tube volumes over 120 days. 
among others. Thus, it can be said that the seedling's growth rate throughout the production phase is clearly related to the volume of the container in which is produced.

Similar behavior was observed by Ferraz \& Engel (2011) and Lisboa et al. (2012) for different forest species, in which smaller tubes used during production led to lower seedling growth.

For seedlings produced in the other two tubes with higher volumes (180 and $280 \mathrm{~cm}^{3}$ ), it was possible to observe a difference in growth after only 105 days in the nursery, whereby seedlings produced in $180 \mathrm{~cm}^{3}$ tubes presented less growth for height and diameter compared to those produced in $280 \mathrm{~cm}^{3}$ tubes (Table 1 ).

This difference is probably related to the greater growth space for the root system, and consequently for shoot growth.

The shoot dry mass (SDM) and root dry mass $(\mathrm{RDM})$ variables were affected as a result of container volume in the periods evaluated, as shown in Table 2. Tubes with higher volumes allowed greater root and shoot dry mass gains when compared to containers with lower volumes, evidencing a direct relation between dry mass gain and container volume.
Alves et al. (2012) for Anadenanthera macrocarpa and José et al. (2009) for Schinus terenbinthifolia found similar results, whereby containers with higher volumes led to greater shoot and root dry biomass production.

It was found that the use of higher volume tubes $\left(180\right.$ and $\left.280 \mathrm{~cm}^{3}\right)$ allowed SDM gains of 3.8 and 4.76 times greater, respectively, at 90 days, in comparison to tubes with the lowest volume $\left(55 \mathrm{~cm}^{3}\right)$; and gains of 4.82 and 7.27 times (tubes of 180 and $280 \mathrm{~cm}^{3}$, respectively) higher for RDM in comparison to $55 \mathrm{~cm}^{3}$ tubes.

The same behavior is observed for the seedlings remaining in the nursery for 120 days, where seedlings produced in $280 \mathrm{~cm}^{3}$ tubes presented greater gains, but did not differ from $180 \mathrm{~cm}^{3}$ tubes for RDM (Table 2). However, the difference in gains was in smaller proportions in comparison to smaller volume tubes; 2.89 and 3.50 for SDM, and 3.31 and 3.17 for RDM in tubes of 180 and $280 \mathrm{~cm}^{3}$, respectively.

According to Freitas et al. (2013), the highest production of shoot and root dry mass was for variables of great importance for the survival and initial development of the seedlings after planting due to greater biomass gains.

Regardless of the production system and the species being produced, the container used should cause the

Table 1. Average height (H) and diameter (D) of Enterolobium contortisiliquum seedlings at 45, 60, 75, 90, 105 and 120 days after sowing, produced in three tube volumes.

\begin{tabular}{|c|c|c|c|c|c|c|c|c|}
\hline \multirow{3}{*}{ Periods } & \multicolumn{3}{|c|}{$\mathrm{H}(\mathrm{cm})$} & \multirow{3}{*}{$\begin{array}{l}\text { CV } \\
(\%)\end{array}$} & \multicolumn{3}{|c|}{$\mathrm{D}(\mathrm{mm})$} & \multirow{3}{*}{$\begin{array}{l}\text { CV } \\
(\%)\end{array}$} \\
\hline & \multicolumn{3}{|c|}{ Tubes $\left(\mathrm{cm}^{3}\right)$} & & \multicolumn{3}{|c|}{ Tubes $\left(\mathrm{cm}^{3}\right)$} & \\
\hline & 55 & 180 & 280 & & 55 & 180 & 280 & \\
\hline 45 & $8.8 \mathrm{~b}$ & $14.9 \mathrm{a}$ & $14.6 \mathrm{a}$ & \multirow{6}{*}{3.3} & $2.05 \mathrm{~b}$ & $3.12 \mathrm{a}$ & $3.09 \mathrm{a}$ & \multirow{6}{*}{3.0} \\
\hline 60 & $9.0 \mathrm{~b}$ & $15.5 \mathrm{a}$ & $15.7 \mathrm{a}$ & & $2.46 \mathrm{~b}$ & $4.02 \mathrm{a}$ & $4.06 \mathrm{a}$ & \\
\hline 75 & $10.7 \mathrm{~b}$ & $15.7 \mathrm{a}$ & $15.7 \mathrm{a}$ & & $2.80 \mathrm{~b}$ & $4.58 \mathrm{a}$ & $4.68 \mathrm{a}$ & \\
\hline 90 & $9.8 \mathrm{~b}$ & $16.9 \mathrm{a}$ & $16.8 \mathrm{a}$ & & $2.98 \mathrm{~b}$ & $5.00 \mathrm{a}$ & $5.13 \mathrm{a}$ & \\
\hline 105 & $10.1 \mathrm{c}$ & $17.9 \mathrm{~b}$ & $18.6 \mathrm{a}$ & & $3.10 \mathrm{c}$ & $5.16 \mathrm{~b}$ & $5.40 \mathrm{a}$ & \\
\hline 120 & $10.6 \mathrm{~b}$ & $19.0 \mathrm{a}$ & $19.6 \mathrm{a}$ & & $3.23 c$ & $5.39 \mathrm{~b}$ & $5.62 \mathrm{a}$ & \\
\hline
\end{tabular}

Means followed by the same letters in the line within the same period do not differ between themselves by Tukey test at $5 \%$ probability.

Table 2. Averages of shoot dry mass (SDM) and root system dry mass (RDM) (g) of Enterolobium contortisiliquum seedlings at 90 and 120 days after sowing, produced in three tube volumes.

\begin{tabular}{|c|c|c|c|c|c|c|c|c|}
\hline & & 90 days & & \multirow{3}{*}{$\begin{array}{l}\text { CV } \\
(\%)\end{array}$} & \multicolumn{3}{|c|}{120 days } & \multirow{3}{*}{$\begin{array}{l}\text { CV } \\
(\%)\end{array}$} \\
\hline & \multicolumn{3}{|c|}{ Tubes $\left(\mathrm{cm}^{3}\right)$} & & \multicolumn{3}{|c|}{ Tubes $\left(\mathrm{cm}^{3}\right)$} & \\
\hline & 55 & 180 & 280 & & 55 & 180 & 280 & \\
\hline DMS (g) & $0.25 \mathrm{c}$ & $0.95 \mathrm{~b}$ & $1.19 \mathrm{a}$ & 18.31 & $0.54 \mathrm{c}$ & $1.56 \mathrm{~b}$ & $1.89 \mathrm{a}$ & 12.57 \\
\hline DMR (g) & $0.11 \mathrm{c}$ & $0.53 \mathrm{~b}$ & $0.80 \mathrm{a}$ & 24.62 & $0.42 \mathrm{~b}$ & $1.39 \mathrm{a}$ & $1.33 \mathrm{a}$ & 22.32 \\
\hline
\end{tabular}

Means followed by the same letters in the line within the same period do not differ between themselves by Tukey test at $5 \%$ probability. 
least possible deformation to the seedling's root system, as this will have a direct effect on shoot growth and on field performance.

In terms of the root deformation percentage, it was found that $55 \mathrm{~cm}^{3}$ tubes presented the highest mean values for both 90 and 120 days (27.62 and 195.17\%, respectively), differing from 180 and $280 \mathrm{~cm}^{3}$ tubes (Figure 2).

No differences in the root deformation percentage were found when the seedlings were produced in 180 and $280 \mathrm{~cm}^{3}$ tubes, regardless of the period evaluated. It was also found that the permanence of the seedlings for a period greater than 90 days, regardless of the volume of the container used, caused an increase in root deformations, ranging from 7 to 9 times higher depending on the volume of the tubes, which may indicate that the seedling is undergoing serious growth restrictions.

According to Auer \& Santos (2011), longer stays for seedlings in the nursery can lead to root deformation such as folding/knotting. This was also verified by Freitas et al. (2005) in Eucalyptus grandis and E. saligna seedlings produced in $50 \mathrm{~cm}^{3}$ tubes, which showed deformations in their roots and influenced their growth in the field.

The lowest number of leaves was found in seedlings produced in the container with the lowest volume, with no difference between the larger volume containers (Table 3).

This lower leaf production was also found by Brachtvogel \& Malavasi (2010) in Peltophorum dubium seedlings, and by Mesquita et al. (2011) in Genipa Americana seedlings when containers with reduced volumes were used.

The higher number of leaves may be a positive variable for seedling growth in the field, since they will have a larger area for production of photoassimilates, which aids growth in the field.

This difference in the performance of seedlings produced in smaller tubes may not only be related to the fact that the volume the seedlings have for growth is reduced, but also due to the lower availability of water and nutrients directly affecting biomass gains.

From the average daily increase in height (ADIH) and diameter (ADID) shown in Figure 3, it can be observed that the point corresponding to the minimum increment in height for 180 and $280 \mathrm{~cm}^{3}$ tube seedlings

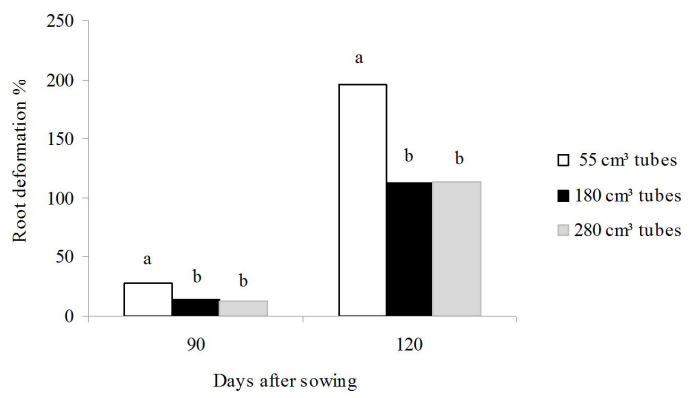

Figure 2. Root system deformation percentage for Enterolobium contortisiliquum seedlings at 90 and 120 days after sowing, produced in three tube volumes. Means followed by the same letter within the same evaluated period do not differ among themselves by the Tukey test at the $5 \%$ probability level.

Table 3. Average number of leaves (NL) of Enterolobium contortisiliquum seedlings 120 days after sowing produced in three tube volumes.

\begin{tabular}{|cc|}
\hline Treatments & NL \\
\hline $55 \mathrm{~cm}^{3}$ tubes & $4.67 \mathrm{~b}$ \\
\hline $180 \mathrm{~cm}^{3}$ tubes & $10.21 \mathrm{a}$ \\
\hline $280 \mathrm{~cm}^{3}$ tubes & $11.08 \mathrm{a}$ \\
\hline $\mathrm{CV}(\%)$ & 16.59 \\
\hline
\end{tabular}

The same means in the column did not differ statistically by Tukey test at $5 \%$ probability.

was at 65 and 67 days, respectively, with no minimum increment point for seedlings produced in $55 \mathrm{~cm}^{3}$ tubes.

It can be observed that with the use of higher-volume tubes $\left(180\right.$ and $\left.280 \mathrm{~cm}^{3}\right)$, the times for minimum height increases occurred almost simultaneously, coinciding with the point at which seedlings achieved the standard in height to be introduced into the field, as can be observed in Table 1. In this regard Carneiro (1995), states that seedlings should reach heights of between 15 and $25 \mathrm{~cm}$.

In relation to the average daily increment in diameter (ADID), maximum and minimum points for the seedlings produced in $55 \mathrm{~cm}^{3}$ tubes were not found. For seedlings produced in $180 \mathrm{~cm}^{3}$ tubes, the maximum and minimum increase occurred at 26 and 91 days of production, while for $280 \mathrm{~cm}^{3}$ tubes, it occurred at 24 and 95 days after planting, respectively (Figure 3).

To determine the period of permanence for Eucalyptus grandis seedlings in nurseries using $53 \mathrm{~cm}^{3}$ tubes, Reis et al. (2008) evaluated morphological variables recommending the period of 100 days after 

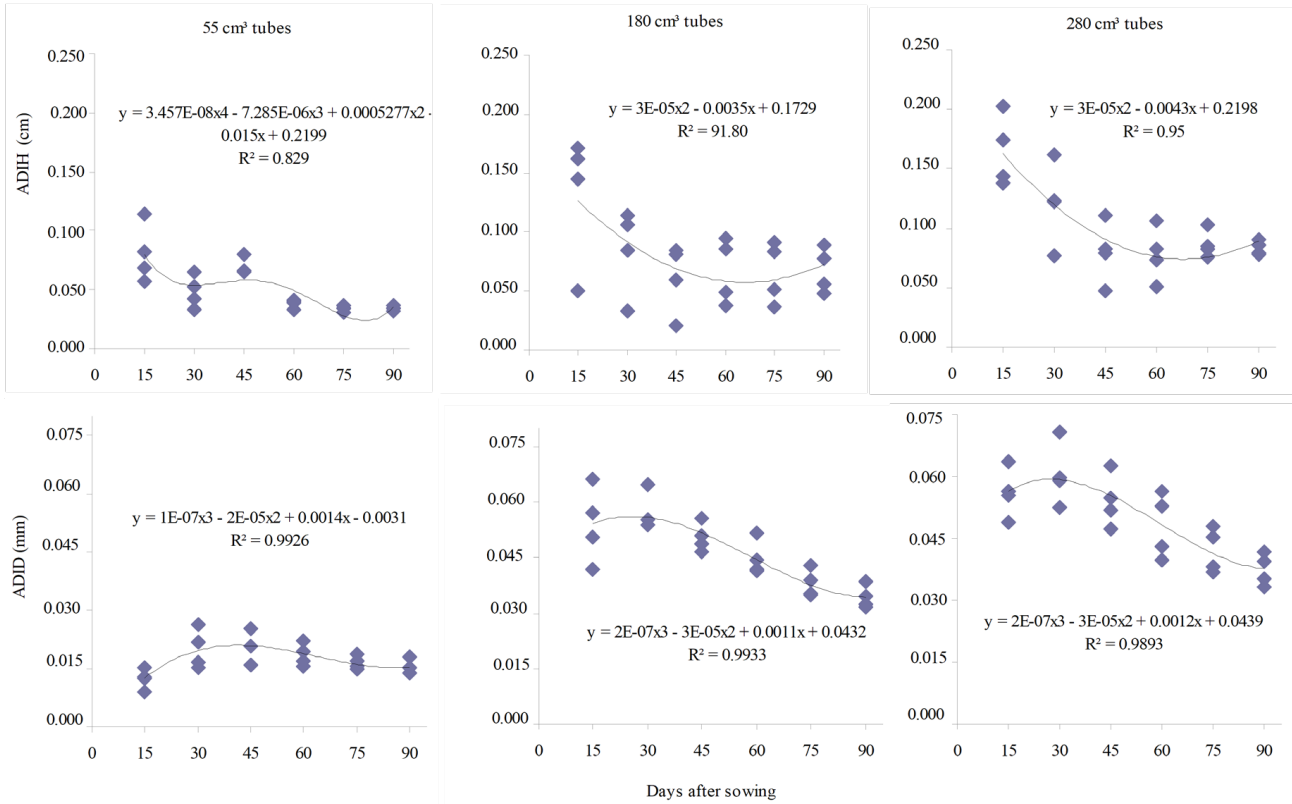

Figure 3. Average diary increment in height (ADIH) and diameter (ADID) of Enterolobium contortisiliquum seedlings over 120 days after planting, produced in three tube volumes.

emergence for the release of seedlings. Mafia et al. (2005) emphasize that seedlings exposed to an excessive period in the nursery present reduced growth, as well as root deformation. This fact was also observed in the present study, in which seedling permanence for a period of more than 90 days reduced incremental gains and increased the deformation percentage.

When evaluating the growth cycle of Eucalyptus seedlings in 55 and $180 \mathrm{~cm}^{3}$ tubes, Freitas et al. (2013) found that seedlings of this species produced in $180 \mathrm{~cm}^{3}$ tubes had higher growth for the analyzed variables, and that the seedlings were able to be planted after 60 days when in higher-volume tubes, while seedlings produced in smaller tubes only reach the minimum standard required for planting in the field at 120 days.

Thus, it can be verified that at the moment the seedlings reach the minimum increment, the growth rate of the seedlings is slower, possibly due to the limited substrate volume for its development. Therefore, seedlings produced in larger volume containers could already be taken to the field at around 90 days, reducing seedling permanence in the nursery by at least 30 days.

When simulating field conditions, the seedlings' behavior after planting was similar to that found in the nursery, in which the seedlings produced in tubes with reduced volumes $\left(55 \mathrm{~cm}^{3}\right)$ were inferior in height and diameter to those produced in larger volume containers (Figure 4) throughout the assessed period of 120 days.

It is also observed that seedlings that exhibited the highest values for height and diameter at the moment of planting into bags (those produced in containers of 180 and $280 \mathrm{~cm}^{3}$ ), maintained the same behavior throughout the 120 days. This leads us to consider that Enterolobium contortisiliquum seedlings can be produced in $180 \mathrm{~cm}^{3}$ tubes, which would result in the use of reduced space and resources for seedling production.

In studying the behavior of Cordia trichotoma (Vell.) Arrab. ex Steudand Jacaranda micranta Cham. in the field, Malavasi \& Malavasi (2006) also found the same behavior for seedlings produced in smaller containers, and this difference was maintained throughout the 180-day assessment period.

On the other hand, in analyzing Schinus terebinthifolius Raddi, José et al. (2005) reported that differences in height and diameter at the moment of planting tend to disappear in seedlings produced in containers of different volumes, with this lack of difference being observed at 250 days after planting. This was similar to data obtained by Correia et al. (2013) in 

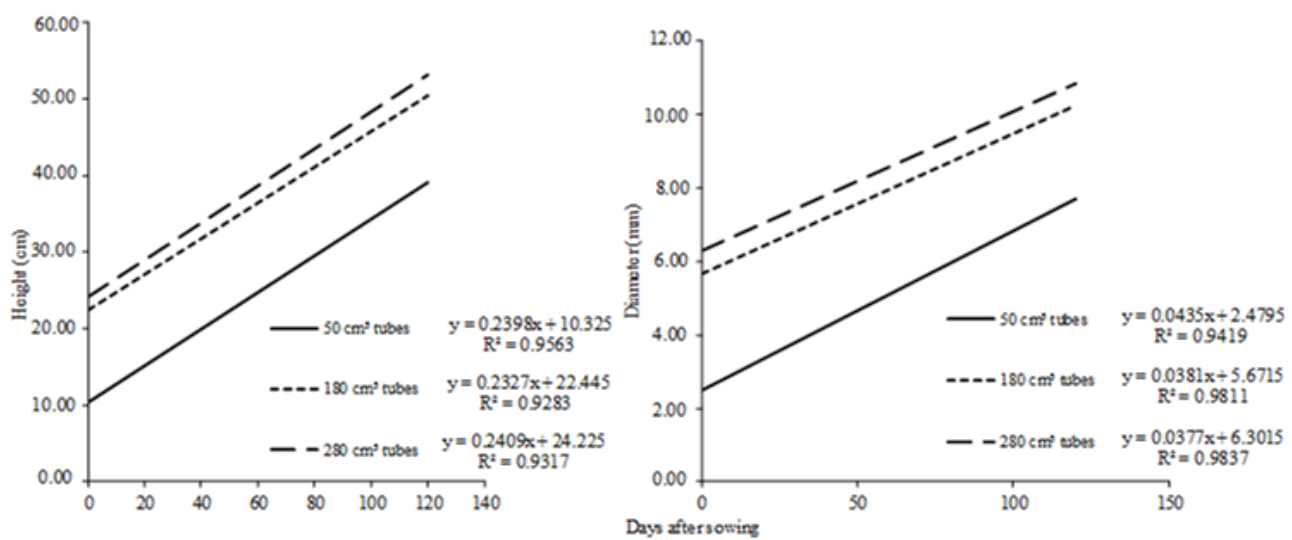

Figure 4. Height and diameter of Enterolobium contortisiliquum (vell.) Morong seedlings, produced in three tube sizes over 120 days in the field.

Table 4. Shoot dry mass (SDM), root dry mass (RDM) and root and shoot dry mass ratio (RDM/SDM) of Enterolobium contortisiliquum seedlings produced in different volume tubes, 120 days after planting in bags.

\begin{tabular}{cccc} 
Treatments & SDM $(\mathbf{g})$ & RDM $(\mathbf{g})$ & RDM/SDM \\
$50 \mathrm{~cm}^{3}$ tubes & $9.82 \mathrm{~b}$ & $8.35 \mathrm{a}$ & $0.56 \mathrm{a}$ \\
$180 \mathrm{~cm}^{3}$ tubes & $12.74 \mathrm{ab}$ & $8.75 \mathrm{a}$ & $0.55 \mathrm{a}$ \\
$280 \mathrm{~cm}^{3}$ tubes & $15.64 \mathrm{a}$ & $9.46 \mathrm{a}$ & $0.63 \mathrm{a}$ \\
\hline Overall mean & 12.73 & 8.85 & 0.58 \\
\hline
\end{tabular}

Averages followed by the same letter within a single variable do not differ statistically from each other by Tukey test at $5 \%$ probability.

Eucalyptus urograndis, who found a trend of equal growth in treatments at 12 months in relation to height, crown circumference and diameter at ground level.

Nonetheless, Freitas et al. (2006) argue that the most critical period of crop-weed competition occurs in the first few months after planting, during which, seedlings cannot circumvent this critical condition, thereby increasing weed-control expenses and delays in expected production.

Table 4 shows data for shoot dry mass, root dry mass, and shoot and root dry mass ratio, 120 days after transplantation into bags.

Regarding the tube size (100 and $\left.280 \mathrm{~cm}^{3}\right)$, Gasparin et al. (2014) found a significant difference in root dry mass, in which higher averages were observed for the largest container, leading to the conclusion that this may favor the growth of post-planted seedlings.

In analyzing Eucalyptus urophylla, Eucalyptus robusta and Corymbia citriodora seedlings in 55 and $180 \mathrm{~cm}^{3}$ tubes, Freitas et al. (2013) found that the tube size and species acted together for the shoot dry mass variable. Those planted in the $180 \mathrm{~cm}^{3}$ tubes had a higher growth at 120 days and presented double the gain for root dry mass. Alves et al. (2012) analyzed Anadenanthera macrocarpa seedlings and reported a significant effect of the containers for shoot dry mass and root dry mass, 120 days after emergence, in which larger containers presented higher biomass.

Gasparin et al. (2014) claim that making evaluations in the field over longer periods is necessary in order to confirm the differences between the seedling production methods used in the nursery, thereby allowing comparisons for the variables that represent good-quality seedlings in both situations.

Therefore, by analyzing all evaluated variables, it was possible to note that the use of $180 \mathrm{~cm}^{3}$ tubes can be recommended to produce seedlings of this species, in addition to reducing the production cycle of the seedlings. Similar data were recorded by Ajala et al. (2012), in which the use of lower-volume tubes led to savings related to substrate, transport and easier planting in the field. 


\section{CONCLUSION}

Seedlings in tubes with higher volumes $\left(180\right.$ and $280 \mathrm{~cm}^{3}$ ) presented adequate conditions for planting at 90 days, while seedlings produced in lower volume tubes $\left(55 \mathrm{~cm}^{3}\right)$ were only adequate at 120 days.

Similarities were observed between $180 \mathrm{~cm}^{3}$ and $280 \mathrm{~cm}^{3}$ tubes, in which the use of $180 \mathrm{~cm}^{3}$ tubes for 90 days is recommended for this species to achieve lower production costs.

\section{SUBMISSION STATUS}

Received: 10 nov., 2015

Accepted: 20 aug., 2017

\section{CORRESPONDENCE TO}

\section{Teresa Aparecida Soares Freitas}

Centro de Ciências Agrárias, Ambientais e Biológicas, Universidade Federal do Recôncavo da Bahia - UFRB, Rua Rui Barbosa, 710, Campus Universitário, CEP 44380-000, Cruz das Almas, BA, Brasil

e-mail: tas_freitas@hotmail.com

\section{REFERENCES}

Ajala MC, Aquino NF, Malavasi UC, Malavasi MM. Efeito do volume do recipiente na produção de mudas e crescimento inicial de Jatropha curcas L. no oeste paranaense. Semina: Ciências Agrárias 2012; 33(6): 2039-2046. http://dx.doi. org/10.5433/1679-0359.2012v33n6p2039.

Alves AS, Oliveira LSB, Andrade LA, Gonçalves GS, Silva JM. Produção de mudas de angico em diferentes tamanhos de recipientes e composições de substratos. Revista Verde de Agroecologia e Desenvolvimento Sustentável 2012; 7(2): 39-44.

Andrade JCM. Fitotransporte de metais em espécies arbóreas e arbustivas em aterro de resíduos sólidos urbanos (Rio de Janeiro) [tese]. Rio de Janeiro: Universidade Federal do Rio de Janeiro; 2005.

Araújo AP, Sobrinho SP. Germinação e produção de mudas de tamboril (Enterolobium contortisiliquum (Vell.) Morong) em diferentes substratos. Revista Árvore 2011; 35(3): 581-588. http://dx.doi.org/10.1590/S010067622011000400001 .

Auer CG, Santos AF. Doenças em eucaliptos destinados à produção de energia na região Sul do Brasil. Pesquisa
Florestal Brasileira 2011; 31(68): 373-379. http://dx.doi. org/10.4336/2011.pfb.31.68.373.

Barbosa TC, Rodrigues RR, Couto HTZ. Tamanhos de recipientes e o uso de hidrogel no estabelecimento de mudas de espécies florestais nativas. Hoehnea 2013; 40(3): $537-$ 556. http://dx.doi.org/10.1590/S2236-89062013000300013.

Brachtvogel EL, Malavasi UC. Volume do Recipiente, adubação e sua forma de mistura ao substrato no crescimento inicial de Peltophorum dubium (Sprengel) taubert em viveiro. Revista Árvore 2010; 34(2): 223-232. http://dx.doi.org/10.1590/S0100-67622010000200004.

Carneiro JGA. Produção e controle de qualidade de mudas florestais. Curitiba: Campos; UENF; 1995.

Correia ACG, Santana RC, Oliveira MLR, Titon M, Atáide GM, Leite FP. Volume de substrato e idade: Influência no desempenho de mudas clonais de eucalipto após o replantio. Revista Ceres 2013; 19(2): 185-191.

Eloy E, Caron BO, Trevisan R, Behling A, Schmidt D, Souza VQ. Determinação do período de permanência de mudas de Eucalyptus grandis W. Hill ex Maiden em casa de vegetação. Revista Comunicata Scientiae 2014; 5(1): 44-50.

Ferraz AV, Engel VL. Efeito do tamanho de tubetes na qualidade de mudas de jatobá (Hymenaea courbaril L. VAR. stilbocarpa (Hayne) Lee Et Lang.), ipê-amarelo (Tabebuia chrysotricha (Mart. ex DC.) Sandl.) e guarucaia (Parapiptadenia rigida (Benth.) Brenan). Revista Árvore 2011; 35(3): 413-423. http://dx.doi.org/10.1590/S010067622011000300005

Freitas TAS, Barroso DG, Carneiro JGA, Penchel RM, Figueiredo FAMMA. Mudas de eucalipto produzidas a partir de miniestacas em diferentes recipientes e substratos. Revista Árvore 2006; 30(4): 519-528. http:// dx.doi.org/10.1590/S0100-67622006000400004.

Freitas TAS, Barroso DG, Carneiro JGA, Penchel RM, Lamônica KR, Ferreira DA. Desempenho radicular de mudas de eucalipto produzidas em diferentes recipientes e substratos. Revista Árvore 2005; 29(6): 853-861. http:// dx.doi.org/10.1590/S0100-67622005000600003.

Freitas TAS, Fonseca MDS, Souza SSM, Lima TM, Mendonça AVR, Santos AP. Crescimento e ciclo de produção de mudas de Eucalyptus em recipientes. Pesquisa Florestal Brasileira 2013; 33(76): 419-428. http://dx.doi. org/10.4336/2013.pfb.33.76.575.

Gasparin E, Avila LA, Araujo MM, Cargnelutti A Fo, Dorneles DU, Oltz BRD. Influência do substrato e do volume de recipiente na qualidade das mudas de Cabralea canjerana (vell.) mart. em viveiro e no campo. Ciência Florestal 2014; 24(3): 553-563. http://dx.doi. org/10.5902/1980509815731.

José AC, Davide AC, Oliveira SL. Produção de mudas de aroeira (Schinus terebinthifolius Raddi) para recuperação 
de áreas degradadas pela mineração de bauxita. Cerne 2005; 11(12): 187-196.

José AC, Davide AC, Oliveira SL. Efeito do volume do tubete, tipo e dosagem de adubo na produção de mudas de aroeira (Schinus terebinthifolia Raddi). Agrarian (Dourados) 2009; 2(3): 73-86.

Lisboa AC, Santos OS, Oliveira S No, Castro DN, Abreu AHM. Efeito do volume de tubetes na produção de mudas de Calophyllum brasiliense e Toona ciliata. Revista Árvore 2012; 36(4): 603-609. http://dx.doi.org/10.1590/S010067622012000400003 .

Lorenzi H. Árvores brasileiras: manual de identificação e cultivo de plantas arbóreas do Brasil. 5. ed. Vol. 1. Nova Odessa, SP: Instituto Plantarum; 2008. 384 p.

Mafia RG, Alfenas AC, Siqueira L, Ferreira EM, Leite HG, Cavallazzi JRP. Critério técnico para determinação da idade ótima de mudas de eucalipto para plantio. Revista Árvore 2005; 29(6): 947-953. http://dx.doi.org/10.1590/ S0100-67622005000600014.

Malavasi UC, Malavasi MM. Efeito do tubete no crescimento inicial de Cordia trichotoma (Vell.) Arrab.
Ex steud e Jacaranda micranta Cham. Ciência Florestal 2006; 16(1): 11-16.

Mesquita JB, Santos MJC, Ribeiro GT, Moura AO. Avaliação da composição de substratos em recipientes na produção de mudas de (Genipa americana L.). Natural Resources 2011; 1(1): 37-45. http://dx.doi.org/10.6008/ESS22379290.2011.001.0004.

Oliveira AB, Medeiros S Fo, Bezerra AME. Tempo de cultivo e tamanho do recipiente na formação de mudas de Copernicia hospital. Acta Scientiarum. Agronomy 2011; 33(3): 533-538. http://dx.doi.org/10.4025/actasciagron. v33i3.5443.

Reis ER, Lúcio ADC, Fortes FO, Lopes SJ, Silveira BD. Período de permanência de mudas de Eucalyptus grandis em viveiro baseado em parâmetros morfológicos. Revista Árvore 2008; 32(5): 809-814. http://dx.doi.org/10.1590/ S0100-67622008000500004.

Trannin ICB, Moreira FMS, Siqueira JO. Crescimento e nodulação de Acacia mangium, Enterolobium contortisiliquum e Sesbania virgata em solo contaminado com metais pesados. Revista Brasileira de Ciência do Solo 2001; 25(3): 743-753. http://dx.doi.org/10.1590/S0100-06832001000300024. 